\title{
Influence of Mediating Variables onto Interdependence between Perceived Difficulties in Balancing Work and Family life and Job satisfaction
}

\author{
Agnieszka Springer (Ph.D) \\ Assistant Professor, Department of Management, Poznan School of Banking \\ Al Niepodległości 2, 61-874 Poznań, Poland \\ E-mail: agnieszka.springer@wsb.poznan.pl
}

Doi:10.5296/ijhrs.v4i3.5970

URL: http://dx.doi.org/10.5296/ijhrs.v4i3.5970

\begin{abstract}
The main purpose of this paper is to assess the influence of mediating variables in the process of perceived work-family conflict onto job satisfaction. The study in question was conducted on the sample of 533 working people, 126 of whom stated that they had a significant problem with balancing work and family life (high WFC) and 269 of whom stated that this problem did not concern them (low WFC). Simultaneously, 136 respondents stated they often brought work problems home (PWtoF) and 278 claimed they did not do that (NPWtoF). The obtained results indicate that the key variables that moderate the influence of the perceived conflict onto job satisfaction are: one's professional position and the subjective work value. In the case of people in managerial and independent positions the perceived work-family conflict does not make job satisfaction decrease. Similar reactions were observed in the case of people for whom work is essential life value. Both the sex of the respondents and the fact that they had children were totally irrelevant in the process. The above mentioned results could become a prerequisite for employers to increase the complexity and autonomy of the tasks entrusted to employees and to create value-based corporate culture.
\end{abstract}

Keywords: work-family conflict, work-family balance, job satisfaction

\section{Reasons for WFC occurrence and shaping WFB}

Job market requirements result in people spending more and more time at work which is the essential part of their lives. Employers expect not only fulfilling entrusted duties and obligations but also full commitment, creativity and loyalty. It is both men and women who face these requirements and the same applies to those who have and do not have children. Simultaneously, employees want to be satisfied with their jobs as work is not only a means of earning a living but it also satisfies higher needs such as the need of appreciation and self-actualization. Empirical research has often proved that there is interdependence between the level of work-life balance (WLB) and job satisfaction. However, this issue is still 
debatable as far as the power and the character of this relation is concerned. WLB is most often defined as the sense of balance, meaning and harmony in various areas of life (Clark et al. 2004), the most significant of which are work and family. This phenomenon is similarly defined by Higgins et al. for whom work-family balance is "perceptual phenomenon characterized by a sense of having achieved a satisfactory resolution of the multiple demands of work and family domains" (Higgins et al., 2000, p. 19). The perception of satisfaction from work-family balance is a construct which comprises both emotional and cognitive elements (Drobnic S., Beham B.2010). In terms of cognitive approach the sense of balance is dependable upon how an individual perceives his or her ability to cope with multiple tasks that stem from achieving goals related to work and family. Perceiving these tasks as possible to accomplish results directly from a given individual's experiences which are rated as either positive or stressful and disproportionate as far one's capabilities are concerned. Emotional compound is the result of cognitive assessment of a given situation and is either a positive or negative emotional reaction to a given situation (Drobnic S., Beham B.2010). Thus, it is not the objective factors such as work conditions or family situation that are essential in terms of the existence of work-to-family or family-to-work conflict but their subjective perception (Boyar et. al. 2007; Moore 2007). In order to identify the results and factors influencing WLB one needs to use subjective methods which identify employee's reactions to requirements related to the realization of family and work roles.

While taking into consideration WFB building process researchers usually concentrate on identifying the level of conflict which refers to the realization of two social roles. This conflict results from the situation in which the requirements connected with realizing one of the roles are perceived as the ones that hinder the realization of the other social role (Greenhaus, and Beutell, 1985). In this case an individual faces significant problems with fulfilling the requirements of a given social role as a result of getting involved into meeting the requirements of another role (Ballout, 2008). The process of building up work-life balance refers not only to conflict but one needs to take into consideration four different areas: work-to-family conflict, family-to-work conflict, work-to-family facilitation, and family-to-work facilitation (Frone 2003). These areas interrelate to each other significantly, which was proved by numerous empirical studies in which the influence of work onto family and family onto work were taken into consideration (Aryee et al., 2005; Huang et al. 2004). The interdependence of what happens at work and in private life is in accordance with widely used spillover theory (Staines, 1980) according to which there is a significant similarity between what happens in private and professional life. An individual transfers emotions, capabilities and attitudes from work to private life and from private life to work. Functioning in both professional and private roles can have both negative consequences of conflict occurrence and the positive ones connected with the enrichment of both these areas (Lourel, 2009). Moreover, functioning in these two areas of life leads to synergy, that is one area influences positively the other (Beutell, 2008). The key importance for building positive influence of work onto family is the possibility of fulfilling individual's psychological needs of autonomy, competence and interdependence (Warner and Hausdorf 2009). Positive emotional experiences resulting from fulfilling needs at workplace lead to the increase in positive emotions at home. Such constructs as work-family positive spillover (Edwards and 
Rothbard, 2000; Hanson 2006), work-family facilitation (Grzywacz, 2002), and work-family enrichment (Greenhaus and Powell, 2006) have been introduced to describe the theoretical relationships and associated mechanisms that enable work and family to benefit from one another. The concept of interdependence of family and professional areas was also developed by S. C. Clark (2000) in Border Theory, according to which people differ from one another in terms of permeability and flexibility of boundaries between work and family areas. The above mentioned conditioning leads to difficulty in indicating a universal model of building up work-family balance and to problems in determining its consequences.

Regardless of the existence of significant interdependence between what happens at work and at home one might face two types of conflict. One of them concerns the influence of work onto family situation and the other one concerns the influence of family situation onto work (Frone 2003; Greenhaus and Bautell, 1985). Separating the influence of work onto family from the influence of family onto work results from the fact that both these dimensions are related with different consequences and are conditioned by different factors (Denise and Rotondo 2008). Simultaneously, people differ from each other in terms of how they cope with conflict (Denise and Rotondo 2008) and also the ability to use positive thinking and direct action contributes to diminishing the sense of conflict in both work-to-family and family-to-work relations. The important factor in this process is the employee's system of values (Boyar, 2008) together with the selected strategy (of either separating or integrating) of coping with the duality of realized role (Ballout, 2008), and the decision making process (Powell and Greenhaus 2006). It is also the factors connected with the character of the job that can contribute to various perceptions of WFC and WFF. One needs to consider a very specific situation of people who perform jobs of emotional character for whom WFB is much more difficult to achieve (Seery et al. 2008). The level of WFB will be also affected by individual variables such as abilities and capabilities, and expectations towards work and professional career and these factors play a more significant role in family-work conflict than in work -family conflict (Ballout 2008).

While analyzing definitions of building up the balance between work and family one might notice approaches in which it is not work-family balance that is taken into consideration but work-life balance as well (Eikhof et al. 2007; Pichler 2009; Allis and O'Driscoll 2008). It is true that an individual functions not only in the areas of work and family, but gets involved in other activities such as those connected with personal interests or associated with a particular social group, however it is still work and family that are most important. On the basis of the data gathered by the author among Polish workers the most significant value is family (rated as number 1 by $71 \%$ of the respondents, and as number 2 by $12 \%$ of respondents), the second important value was work (rated as number 1 by $7 \%$ and as number 2 by $49 \%$ of respondents) (Springer 2011). Therefore, further discussion will concentrate on the relationship between functioning in family and professional spheres of life.

\section{Positive and negative consequences of functioning in family and professional areas.}

Maintaining balance between one's professional and family life is a significant factor influencing the functioning of an individual in the workplace. To what extent we feel satisfied with the realization of both roles - family and professional ones - influences our emotions, 
attitudes and behavior of employees, and then, as a consequence, it influences the efficiency of the whole organization (Eby et. Al., 2005). The consequences of functioning in those two spheres of life could be both positive and negative. In the case of imbalance and the perception of work-family conflict multiple negative consequences can be observed. Workers' absenteeism, lateness, inclination towards giving up their job, burn-out syndrome or other negative behavior are expected to increase (Frone 2003; Boyar et. al. 2005, 2008; Hassan, 2008; Hughes and Bozionelos 2007; Malik, 2010).

On the other hand, corporate actions aimed at facilitating worker's WLB can contribute to many positive aspects including, apart from job satisfaction, increased devotion and attachment to organization and organizational citizenship behavior (OCB) Kossek and Ozeki, 1998; Lambert, 2000; Allen, 2001; Thomas and Protas, 2005; Hackman and Oldham, 1976). Bearing in mind the remaining positive results, the author in her own research concentrated on job satisfaction stating the hypothesis according to which people experiencing work-life balance will sense more job satisfaction when compared to those who have problems with balancing these two spheres of life.

Satisfaction, including job satisfaction, according to social sciences is linked to the possibility of realizing by an individual his or her needs, goals, values and beliefs (Bartkowiak 2009). This possibility of realization of one's own values and goals is perceived as the basis for shaping worker's attitude towards his or her job. It was V. H. Vroom who defined satisfaction as an attitude, which means that positive attitude towards work is identical with job satisfaction (Vroom 1964). He developed his deliberations into well-known expectancy theory of motivation according to which the prerequisite of satisfaction is the realization of one's expectations. Another classical researcher into organizational behavior E.A. Locke - defines job satisfaction as a result of one's perception of work which makes it possible to achieve important values from work on condition that these values are in accordance with the individual needs or help in realizing basic human needs (Locke 1976). According to the above mentioned definition what is perceived in work as valuable will directly result from the employee's inherent needs, while achieving results valued by the employee is identical with his satisfaction. P. E. Spector, on the other hand, diverges from the significance of human needs in feeling job satisfaction and states that it is cognitive processes that play a dominant role in shaping attitudes towards work, whose key element is worker's satisfaction (Spector 1997). P. K. Nair also defines satisfaction as an attitude which is based on the individual assessment of one's own workplace, which means that this satisfaction comprises more than just feelings - it also reflects the assessment and perception of one's own work (Nair 2007).

Satisfaction is perceived not only in the workplace. The perception or lack of perception of conflict will influence satisfaction in family relations as well. In the empirical research conducted by O'Driscol et al. (2004) a differentiation between the influence of work onto family and family onto work together with the assessment of job satisfaction and family life satisfaction was made. The results indicate that there exists influence of work-to-family relation onto job satisfaction while there are no significant results indicating similar interdependence between family-to-work influence onto family life satisfaction. Simultaneously, family life satisfaction influences work satisfaction and vice versa 
(O'Driscol et al., 2004), which confirms transferring positive and negative emotional states from one sphere of life into another. The research conducted by Allis and O'Driscoll (2008) proved that the time devoted to nonprofessional activities has a positive influence onto work satisfaction and quality of life.

The process of building up satisfaction and engagement by means of activities supporting WFB is dependent upon multiple situational and individual factors, which is why researchers have undertaken multiple attempts to determine mediating variables in this very process (Beutell and Witting - Berman, 2008; Wayne et. al., 2004, 2005, Aryee, et. al. 2005; Hsu, 2011). Scientists point out that such elements as family life cycle phase, cultural and social conditioning, personal characteristics and locus of control play a crucial role in this process. The differences in the way of building up work-to-family relation and various reactions to the conflict can be observed among people coming from different generations (Beutell and Witting - Berman, 2008; Heraty et al. 2008) and people of different sexes. Men and women react differently to situations triggering work-family conflict and this reaction is dependable upon the perception of one's own family role (Biggs and Brough 2005). A clearly perceived family role in the case of women reinforces WFC, while in the case of men it lowers the perceived WFC.

While taking into consideration various interdependences of mediating variables in the process of the perceived work-family conflict onto job satisfaction special attention was paid to sex, having a baby, position at work, the value attributed to work and perceived tiredness.

\section{Elements of personal policy supporting WFB}

The awareness of positive consequences of WLB makes organizations implement personal policy enabling the worker to be satisfied with both social roles in question. Unfortunately, the results of these activities are not often in line with workers' expectations. Multiple studies show that the activities undertaken by organizations in order to support work-life balance do not lead to expected results (Straub 2007, Cloutier 2011). Due to the diversity of conducted research one can observe disagreement pertaining to the role of personal policy in the process of building up work-family balance among the authors. Some researchers claim that formal activities are insignificant (Baral, Bhargava, 2010) while others claim that they are essential (Marcinkus et. al. 2007, Saltzstein et. al. 2001). The described above situation should make organization look into the issue of creating such personal policy that would support WLB and try to find out which elements of this policy really contribute to increasing worker's satisfaction in both roles - the family role and the professional one. Unfortunately, despite numerous studies into the usage of various organizational means supporting WLB it is extremely difficult to find the answer to the question. Finding appropriate solutions is difficult because people of different sexes, those having different systems of value and those with different personalities have different expectations. The level of perceived work-family conflict can be also dependent on situational variables, including economic situation - the more difficult the economic situation, the more noticeable the conflict (Schieman and Young 2011).

The factors influencing WFC are work requirements. The higher the workload the 
higher is the sense of conflict (Drobnic, Beham 2010). One of the most crucial elements of perceived workload is the time of work, long hours spent at work and work at weekends, which increase the level of dissatisfaction and problems in the relations with family members (Peetz et al. 2011). It is not only the number and kind of tasks entrusted to the employee that influence the level of perceived workload, but also the time that can be devoted to realizing these tasks. When employees perceive their work as more complex and more autonomous a higher degree of work-to-family enrichment can be observed, which contributes to the increase in satisfaction, emotional attachment and OCB (Baral, Bhargava, 2010). Therefore, elements of job characteristics and the sense of autonomy can neutralize negative consequences in work-to-family relation.

One of the areas of human resource policy which is seen as quite controversial is flextime, including teleworking. Flextime and part-time work should support reconciliation of work and family roles, however, as the research shows, they can result in both the increase (Bilal et al.) and the decrease in job satisfaction (Saltzstein et. al. 2001). That is why it is not certain that flextime policy will be beneficiary for both the employee and the employer. The problem becomes even more vivid in the situation in which this system of work is undertaken out of necessity not out of employee's own choice. Research confirms that although flexibility, including flextime, is important for employees, they decide to take such work, for example work from home, only because they have to (Walker et. al. 2008; Kowalewski ed. 2007) as it is most often not the employee but the employer who is the initiator of telework (Tramblay et al. 2006). One needs to bear in mind that the relation between the place of work (office, home, client's place) and job satisfaction is ambiguous (Morganson et al., 2010), which is why mediating variables, including worker's needs, will play an important role in this process. Similarly as the flexibility of the workplace, also the flexibility of work time, which in theory should support the reconciliation of work and family obligations, does not necessarily stimulate the increase in worker's satisfaction. Sometimes it is just contrary to what one might expect, namely the increase in the flexibility of, for example, working time lowers job satisfaction (Tausig, and Fenwick, 2001). When trying to use the influence of flextime onto building up WFB, workers' satisfaction from the offered solutions should also be assessed (Beutell 2010). This problem is of great significance as both the length and the organization of the working time is a basic factor influencing WLB (Pichler 2009). Whether making working conditions more flexible will result in positive consequences in the long perspective depends on multiple factors, including individual factors (Moore, 2007).

In organizations which lack formal solutions the key element is the manager's approach towards his or her subordinates (Hyman and Summers 2007). Support from management and coworkers together with family support, positively influences WFB and the sense of satisfaction. The notion of social support, including management support, is addressed in many studies (Drobnic, Beham 2010; Wadsworth and Owens, 2007; Baral, Bhargava, 2010, 2011, Marcinkus et. al. 2007; Md-Sidin, 2010; Hsu, 2011). Therefore, it is not surprising that it is not only the range and instruments of human resource policy that can influence WFB, but corporate culture is also a key element in this process. In organizations which create corporate culture supporting family positive outcomes, such as the increase in involvement were observed. On the other hand, in those organizations in which corporate 
culture created obstacles in building up WLB an increase in WFC and in exhaustion were observed (Peeters et al. 2009). Simultaneously, support from a spouse decreases the negative influence of WFC, especially when referring to people who have children under the age of 6 (Melrona and Finian 2004).

Selection of human resource policy elements makes it more difficult to differentiate workers' reactions. What is perceived as a source of satisfactions by some workers can be viewed as an impediment by others. The differences concerning human resource policy are observed between men and women (Baral and Bhargava 2011; Gallie and Russell 2009), however, it seems that the variable is becoming less and less differentiating. Some studies indicate that there are clear differences between expectations in the range of desired elements of human resource policy at different organization levels (Moore 2007, Kasper et. al. 2005), others, however, indicate that the character of the interdependence between WLB and satisfaction is independent of the professional position (Saif et al. 2011). The differentiation of corporate activities supporting the process of building up work-family satisfaction requires knowledge on needs and expectations in particular work groups.

\section{Purpose of the study and methodology}

\subsection{Questions and research hypotheses}

The variety of studies indicates that both the level of perceived WFC and the interdependence between WFC and satisfaction can be influenced by both objective and subjective variables. The purpose of the study was to determine the influence of selected objective and subjective variables onto the interdependence between the perceived conflict and job satisfaction. Sex, family status (having a child under the age of 7), and professional position were among objective variables while the subjective ones were the perceived level of tiredness and the value attributed to work.

The following problems and resulting from them hypotheses were formulated:

1 : What is the interdependence between the perceived conflict and job satisfaction?

H1a: Job satisfaction is correlated negatively with the perceived work-family conflict and with bringing work home

2. What is the role of objective variables in the relationships between WFC and PWtoH, and between WFC and JS?

H2a: Men and women differ from each other while regarding the influence of WFC and PWtoH onto JS

$\mathrm{H} 2 \mathrm{~b}$ : Having a child under the age of 7 influences the relationship between WFC and PWtoH and between WFC and JS.

H2c: Professional position influences the relationship between WFC and PWtoH and between WFC and JS

3. What is the role of subjective variables in the relationship between WFC and PWtoH and between WFC and JS?

H3a: Perceived tiredness differentiates the relationship between WFC and PWtoH and between WFC and JS

H3b: Perceived value of work differentiates the relationship between WFC and PWtoH and 
between WFC and JS 2014, Vol. 4, No. 3

\subsection{Research methodology}

\subsubsection{Study sample}

Conducted analysis was a part of a broader study connected with workers' attitudes conducted in Poland in 2011.The study was conducted on a sample of 533 working individuals, $52 \%$ of whom were men and $48 \%$ were women. The sample was diverse in terms of age: $16 \%$ were people under the age of $24,28 \%$ - people at the age of $25-34,24 \%$ - people at the age of $35-44,21 \%$ - people at the age of $45-54$ and $11 \%$ were people at the age of 55 and older. People with education lower than secondary constituted $32 \%$ of the sample, those with secondary education - 37\%, and those with higher education - $31 \%$. The people were employed in different organizations: $18 \%$ were employed in institutions and administration, $38 \%$ - in services, $21 \%$ - in trade and $23 \%$ - in a production sector. One out of five people worked in a company employing fewer than 10 people, 34\% worked for a company employing between 10 and 49 workers, 23\% - in companies employing 50-249 workers and $23 \%$ - for the largest employers. The above mentioned differentiation reflects, while taking into consideration the most important criteria, the structure of employees in the region under study.

\subsubsection{Measurement}

Worker satisfaction scale comprising 16 positions was used to verify the research hypotheses. Respondents assessed the level of their satisfaction on a five-range scale while taking into consideration 16 different aspects of their work connected with the needs of affiliation, power, appreciation and development (see table 1). Reliability analysis measured by means of Cronbach's alpha coefficient was 0.893 , which makes it possible to acknowledge the scale of job satisfaction as reliable. 
Table 1. Elements of worker's satisfaction measurement

\begin{tabular}{|l|l|}
\hline worker's needs & variables analyzed \\
\hline safety & $\begin{array}{l}\text { complying with Occupational Safety and } \\
\text { Health regulations } \\
\text { clarity of obtained information } \\
\text { employment stability } \\
\text { remuneration level }\end{array}$ \\
\hline affiliation & $\begin{array}{l}\text { contacts with coworkers } \\
\text { relationship with superiors } \\
\text { employer's forbearance } \\
\text { superior's fairness }\end{array}$ \\
\hline $\begin{array}{l}\text { power and } \\
\text { appreciation }\end{array}$ & $\begin{array}{l}\text { availability of information } \\
\text { possibility of promotion } \\
\text { workplace equipment } \\
\text { remuneration system }\end{array}$ \\
\hline development & $\begin{array}{l}\text { possibility of development } \\
\text { type of performed tasks } \\
\text { autonomy of action } \\
\text { flexibility of working time }\end{array}$ \\
\hline
\end{tabular}

Source: own study

The conducted satisfaction assessment was confronted with the assessment of the perceived level of work-family conflict and with the situation of bringing work home. Respondents while using five-range Likert scale took positions towards the following statements: "I find it difficult to balance work and family life" and "I often bring work problems home". First, the character of the interdependence was determined by means of correlation coefficient. Due to the fact that some analyzed variables were ordinal Spearman's rang rho correlation coefficient was used.

Afterwards the assessment of the influence of the perceived conflict onto the perceived satisfaction was conducted by means of the comparison of averages for groups selected on the basis of the analyzed questions. Student's t test was used to assess the significance of differences between the averages. As far as the first question is concerned workers with high level of perceived conflict (high WFC $\mathrm{N}=126$ ) and workers with low level of perceived conflict (low WFC N=269) were distinguished. People who were unable to determine their conflict level were excluded from the analysis. Similar procedure was employed in the case of the second question, dividing the respondents into those who bring work problems home (PWtoH N=136) and those who do not bring work problems home (NPWtoH N=278). Respondents who selected 3 on a 5-range Likert's scale were excluded from the analysis.

\section{Study results}

The major problem concerned the assessment of the relationship between work-family relation and the perceived satisfaction. The correlation coefficient between perceived job satisfaction and perceived difficulties and the situation in which the worker brings work 
problems home was negative, but it was statistically significant only with respect to perceived conflict.

Table 2. Spearman's rho correlation coefficient

\begin{tabular}{|l|l|l|l|}
\hline & & WFC & PWtoH \\
\hline \multirow{3}{*}{ JS_ALL } & correlation coefficient & -.158 & -.046 \\
\cline { 2 - 4 } & binary significance & .000 & .291 \\
\cline { 2 - 4 } & $\mathrm{N}$ & 525 & 525 \\
\hline
\end{tabular}

Source: own study

When comparing the average satisfaction level for people who declared huge problems trying to balance work and family life and other workers one can notice a huge difference (significance level $\alpha=0.045$ ). People who perceived fewer difficulties usually had higher results on the job satisfaction scale. This interdependence was not observed with reference to the issue of bringing work problems home. People who declared that they often brought work problems home did not differ significantly from other workers in terms of perceived satisfaction.

The above analysis allows confirming hypothesis $\mathrm{H} 1$ according to which there is influence of perceived work-family conflict onto job satisfaction.

\subsection{Influence of moderating variables}

The results of conducted analyses indicate that there is, although not very strong but statistically significant, interdependence between satisfaction and perceived difficulties when trying to balance work and family life and people who feel these difficulties are generally less satisfied with their jobs. According to the existing literature different mediating variables that change the character of the interdependence in question could be involved in this process (Beutell and Witting - Berman, 2008; Wayne et. al., 2004, 2005, Aryee, et. al. 2005; Hsu, 2011). One needs to take into consideration especially such variables as sex - which influences the differentiation concerning realized professional role, having children - which increases the obligations concerning childcare and professional position - which changes the character of the work. Bearing all that in mind the analysis of the interdependence of satisfaction and difficulties in balancing professional and family life was conducted with reference to each of the distinguished segments.

Table 3 Spearman's rho correlation coefficient according to sex, having a child under the age of 7 and professional position

\begin{tabular}{|l|l|l|l|}
\hline & & WFC & PWtoH \\
\hline JS_woman & correlation coefficient & $-.165^{* *}$ & .024 \\
\hline & binary significance & .008 & .702 \\
\hline & $\mathrm{N}$ & 255 & 255 \\
\hline JS_man & correlation coefficient & $-.156^{*}$ & $-.120^{*}$ \\
\hline & binary significance & .010 & .048 \\
\hline
\end{tabular}




\begin{tabular}{|l|l|l|l|}
\hline & $\mathrm{N}$ & 270 & 270 \\
\hline JS_with child $<7$ & correlation coefficient & $-.237^{*}$ & -.129 \\
\hline & binary significance & .042 & .273 \\
\hline & $\mathrm{N}$ & 74 & 74 \\
\hline JS_without child $<7$ & correlation coefficient & $-.147^{* *}$ & -.037 \\
\hline & binary significance & .002 & .432 \\
\hline & $\mathrm{N}$ & 451 & 451 \\
\hline JS_ordinary worker & correlation coefficient & $-.235^{* *}$ & -.072 \\
\hline & binary significance & .000 & .231 \\
\hline & $\mathrm{N}$ & 280 & 280 \\
\hline JS_specialist worker & correlation coefficient & -.128 & -.120 \\
\hline & binary significance & .134 & .160 \\
\hline & $\mathrm{N}$ & 139 & 139 \\
\hline JS_manager & correlation coefficient & -.093 & -.032 \\
\hline & binary significance & .342 & .748 \\
\hline & $\mathrm{N}$ & 106 & 106 \\
\hline
\end{tabular}

Source: own study

Conducted analysis indicates that, as in the case of all workers, there is a statistically significant relationship only when perceiving difficulties in balancing work and family life. This interdependence is slightly stronger for women than for men and refers mainly to ordinary workers. In the case of specialists and people in managerial positions there are no interdependences between satisfaction and perceived difficulties. Bringing work home (except for men) is not connected with job satisfaction. The significance analysis of the differences between averages for analyzed groups indicates that the influence of this variable should be disregarded also with respect to working men. The existence of significant interdependence was also disregarded in the case of men and women. It is only the professional position which plays the key role moderating the relation between perceived conflict and job satisfaction. 
Table 4 Average satisfaction level and statistical significance of differences between means for analyzed segments according to sex, having a child under the age of 7 and professional position

\begin{tabular}{|l|l|l|l|l|l|l|}
\hline & \multicolumn{2}{|l|}{ WFC } & \multicolumn{2}{l|}{ PWtoH } \\
\hline Mean & $\begin{array}{l}\text { high } \\
\text { Mean }\end{array}$ & $\begin{array}{l}\text { significanc } \\
\text { e of } \\
\text { difference } \\
\text { s }\end{array}$ & $\begin{array}{l}\text { often } \\
\text { Mean }\end{array}$ & $\begin{array}{l}\text { rarely } \\
\text { Mean }\end{array}$ & $\begin{array}{l}\text { significan } \\
\text { cer of } \\
\text { difference } \\
\text { s }\end{array}$ \\
\hline JS_woman & 55.91 & 58.05 & 0.212 & 56.46 & 56.28 & 0.922 \\
\hline JS_man & 55.05 & 57.64 & 0.124 & 53.90 & 56.89 & 0.058 \\
\hline JS_with child <7 & 56.5 & 59.76 & 0.128 & 56.22 & 57.95 & 0.486 \\
\hline $\begin{array}{l}\text { JS_without child } \\
<7\end{array}$ & 55.3 & 57.56 & 0.105 & 55.04 & 56.36 & 0.307 \\
\hline $\begin{array}{l}\text { JS_ordinary } \\
\text { worker }\end{array}$ & $\mathbf{5 1 . 3 2}$ & $\mathbf{5 5 . 3 2}$ & $\mathbf{0 . 0 2 3}$ & 51.57 & 53.57 & 0.186 \\
\hline $\begin{array}{l}\text { JS_specialist } \\
\text { worker }\end{array}$ & 57.47 & 59.75 & 0.303 & 58.13 & 59.65 & 0.508 \\
\hline JS_manager & 60.63 & 62.46 & 0.469 & 59.80 & 62.08 & 0.314 \\
\hline
\end{tabular}

Source: own study

Therefore, it is the character of the performed work that is decisive in whether perceived difficulties will result in the decrease in job satisfaction. The remaining variables, such as sex or having a child do not play a significant role in the process.

Conducted analysis indicates that hypotheses $\mathrm{H} 2 \mathrm{a}$ and $\mathrm{H} 2 \mathrm{~b}$ should be disproved. It is only hypothesis $\mathrm{H} 2 \mathrm{c}$ according to which the position at work influences the relationship between WFC and job satisfaction that can be positively verified.

The obtained results confirm the notion that there is no influence of individual objective variables such as sex or having a child onto worker's satisfaction stemming from balancing professional and family roles. Thus, it is subjective variables that should be considered decisive in this process.

When taking into consideration subjective variables, it was the value attributed to work and the level of perceived tiredness that were analyzed. It was assumed that people for whom work is either important or very important will not react to such extent to perceived difficulties in balancing family and professional life. Similar assumption was taken when considering people who are less tired. In all these above mentioned segments statistically significant interdependence between satisfaction and difficulties while balancing work and family was observed. 
Table 5 Spearman's rho correlation coefficient according to work importance and perceived tiredness

\begin{tabular}{|l|l|l|l|}
\hline & & WFC & PWtoH \\
\hline $\begin{array}{l}\text { JS_wok less } \\
\text { important }\end{array}$ & correlation coefficient & $-.196^{* *}$ & -.067 \\
\hline & binary significance & .003 & .309 \\
\hline & $\mathrm{N}$ & 235 & 235 \\
\hline JS_work important & correlation coefficient & $-.125^{*}$ & -038 \\
\hline & binary significance & .034 & .524 \\
\hline & $\mathrm{N}$ & 290 & 290 \\
\hline JS_tired & correlation coefficient & $-.183^{*}$ & -.120 \\
\hline & binary significance & .039 & .177 \\
\hline & $\mathrm{N}$ & 127 & 127 \\
\hline JS_not tired & correlation coefficient & $-.137^{* *}$ &.-035 \\
\hline & binary significance & .006 & .487 \\
\hline & $\mathrm{N}$ & 398 & 398 \\
\hline
\end{tabular}

Source: own study

Further analysis of average satisfaction results comparison confirmed moderating influence of the value attributed to work by the worker. With reference to people for whom work is of lower importance one can notice a significant difference in satisfaction levels depending on whether a given person has or does not have problems balancing family and professional life. This interdependence is not noticeable in the case of workers who attribute significant life value to work. However, there is no moderating role of the influence of perceived tiredness onto the WFC-JS relation. One might notice that among people who feel tired at work $\mathrm{PWtoH}$ is negatively related to perceived satisfaction level.

Table 6. Average satisfaction level and statistical significance of the differences between the means for analyzed segments according to the value of work and perceived tiredness

\begin{tabular}{|l|l|l|l|l|l|l|}
\hline & \multicolumn{2}{|l|}{ WFC } & \multicolumn{2}{l|}{ PWtoH } \\
\hline & $\begin{array}{l}\text { high } \\
\text { Mean }\end{array}$ & $\begin{array}{l}\text { low } \\
\text { Mean }\end{array}$ & $\begin{array}{l}\text { significan } \\
\text { ce of } \\
\text { difference } \\
\text { s }\end{array}$ & $\begin{array}{l}\text { often } \\
\text { Mean }\end{array}$ & $\begin{array}{l}\text { rarely } \\
\text { Mean }\end{array}$ & $\begin{array}{l}\text { significan } \\
\text { ce of } \\
\text { difference } \\
\text { s }\end{array}$ \\
\hline $\begin{array}{l}\text { JS_ wok less } \\
\text { important }\end{array}$ & $\mathbf{5 3 . 0 0}$ & $\mathbf{5 6 . 9 7}$ & $\mathbf{0 . 0 3 9}$ & 53.39 & 55.54 & 0.232 \\
\hline JS_wok important & 57.30 & 58.56 & 0.403 & 56.46 & 57.56 & 0.469 \\
\hline JS_tired & 48.42 & 51.56 & 0.128 & $\mathbf{4 6 . 8 0}$ & $\mathbf{5 0 . 7 3}$ & $\mathbf{0 . 0 4 0}$ \\
\hline JS_not tired & 58.55 & 59.60 & 0.451 & 57.98 & 58.44 & 0.718 \\
\hline
\end{tabular}


Source: own study

The obtained results enable to verify positively hypothesis $\mathrm{H} 3 \mathrm{a}$ with reference to the differentiating influence of tiredness onto the interdependence between bringing work home and perceived satisfaction. The obtained results enable also to verify positively $\mathrm{H} 3 \mathrm{~b}$ with reference to moderating influence of the value attributed to work onto the relationship between WFC and JS.

\subsection{Limitations of the study}

Basic limitation of the conducted analyses results from a relatively simple distinction between these workers who find and those who do not find it difficult to balance work and family life and a distinction between those who bring and who do not bring work problems home. The division of workers according to these two criteria was based on a subjective individual assessment made by the worker. Obviously, using a much more complex scale to measure the level of WFC would result in much more precise assessment of the occurrence of this particular phenomenon. However, the conducted study was not aimed at obtaining a detailed diagnosis of the problem but at a simple comparison of the satisfaction level between the workers who perceive and those who do not perceive any problems in the work-family. relation. As far as this goal was concerned the used method of measurement and analysis seems to be satisfactory, especially as it is the subjective feelings of the worker that are the basis for the occurrence of the work-family conflict or lack of this conflict (Boyar et. al. 2007; Moore 2007).

Another problem that might result in a limited implementation of the obtained results is the limited geographical area of the study. Due to cultural and social conditioning and economic situation Polish workers might differ from those coming from other countries in terms of the perceived influence of WFC onto job satisfaction, which is why one needs to be very careful when making generalizations on the basis of the obtained results. Another limitation of the conducted study is also the fact that is focused on job satisfaction and does not take into consideration the influence of the perceived conflict onto family life satisfaction, which might be worth including in further research.

\section{Conclusion}

There is a relationship between WFC and perceived job satisfaction, and although this relationship is statistically significant, it is not very strong $(r=-0.158)$. This results from the fact that there are other factors that influence the satisfaction level. In terms of objective variables that might affect the character of this relation the key one is the professional position. Only among ordinary workers the relationship between perceived problems in balancing family and professional life was positively verified. When taking into consideration specialist workers and managers this relationship was not positively verified. Thus, whether the perceived difficulties in balancing work and family will affect job satisfaction or not, will result from the character of the performed work. The workers whose work was more complex and who were more autonomous, despite perceiving problems when balancing work and family were not less satisfied with their jobs. These results are in accordance with the studies 
stressing the role of autonomy and complexity of assigned tasks in the perceived WFC (Baral, Bhargava, 2010). The conducted analysis suggests that the key to building WFB is the characteristic of the performed work. It is also the workers' attitude towards their work that matters. When taking into consideration people for whom work was of essential value the perceived difficulties in maintaining work-family balance did not result in decreasing job satisfaction. The above mentioned results might be guidelines for practitioners who would like to increase their workers' satisfaction. In the light of the obtained results it seems that the key to success will be not making work more flexible, but rather work enrichment, increase in workers' autonomy and building up corporate culture that promotes values and engagement.

\section{References}

Allen, T.D. (2001). Family-supportive work environments: the role of organizational perceptions. Journal of Vocational Behaviour, Vol. 58 No. 3, 414-35

Allis P., O'Driscoll M. (2008). Positive effects of nonwork-to-work facilitation on well-being in work, family and personal domains. Journal of Managerial Psychology Vol. 23 No. 3, 273-291

Aryee, S., Srinivas, E.S. and Tan, H.H. (2005). Rhythms of life: antecedents and outcomes of work-family balance in employed parents. Journal of Applied Psychology, Vol. 90 No. 1, $132-46$

Ballout H.I. (2008). Work-family conflict and career success: the effects of domain-specific determinants, Journal of Management Development, Vol. 27 No. 5, 437-466

Baral R., Bhargava S.(2010). Work-family enrichment as a mediator between organizational interventions for work-life balance and job outcomes. Journal of Managerial Psychology Vol. 25 No. 3, 274-300

Baral R., Bhargava S., (2011). Examining the moderating influence of gender on the relationships between work-family antecedents and work-family enrichment. Gender in Management: An International Journal, Vol. 26 No. 2, 122-147

Bartkowiak G. (2009). Człowiek w pracy. Od stresu do sukcesu w organizacji. Warszawa: PWE

Beutell N.J. (2010). Work schedule, work schedule control and satisfaction in relation to work-family conflict, work-family synergy, and domain satisfaction, Career Development International Vol. 15 No. 5, 501-518

Beutell, N.J. and Wittig-Berman, U. (2008). Work-family conflict and work-family synergy for generation $\mathrm{X}$, baby boomers, and matures: generational differences, predictors, and satisfaction outcomes. Journal of Managerial Psychology, Vol. 23 No. 5, 507-523

Biggs A., Brough P. (2005). Investigating the Moderating Influences of Gender Upon Role Salience and Work-Family Conflict, Equality. Diversity and Inclusion: An International Journal; 24, 2, 30-41 
Bilal M., Zia-ur-Rehman M., Raza I. (2010). Impact of Family Friendly Policies on Employees' Job Satisfaction and Turnover Intention. Interdisciplinary Journal of Contemporary Research in Business, Vol 2, No 7, 378-395

Boyar S.L., Maertz C.P., Mosley D.C., Carr J.C. (2008). The impact of work/family demand on work-family conflict. Journal of Managerial Psychology Vol. 23 No. 3, 215-235

Boyar, S.L., Carr, J.C., Mosley, D.C. Jr and Carson, C.M. (2007). The development and validation of scores on perceived work and family demand scales. Educational and Psychological Measurement, Vol. 67, 100-15

Boyar, S.L., Maertz, C.P. Jr and Pearson, A. (2005). The effects of work-family conflict and family-work conflict on non-attendance behaviours. Journal of Business Research, Vol. 58, 919-925

Clark S. C. (2000). Work/family border theory: A new theory of work/family balance, Human Relations; Jun 2000; 53, 6, 747- 770

Clarke, M.C., Koch, L.C. and Hill, E.J. (2004). The work-family interface: differentiating balance and fit, Family and Consumer Sciences Research Journal, Vol. 33 No. 2, 121-140.

Cloutier L., Bernard P., Tremblay, D.G. (Spring 2011). Activité professionnelle et responsabilités familiales : les mères sont-elles encore perdantes dans leur qualite d'emploi, Relations Industrielles; 66, 2, 256-278

Denise M., Rotondo J. F. (2008). Conflict, facilitation, and individual coping styles across the work and family domains. Kincaid Journal of Managerial Psychology Vol. 23 No. 5, 484-506

Drobnic S., Beham B., (2010). Satisfaction with work-family balance among German office workers, Journal of Managerial Psychology Vol. 25 No. 6, 669-689

Eby, L.T., Casper, W.J., Lockwood, A., Bordeaux, C. and Brindley, A. (2005). Work and family research in IO/OB: content analysis and review of the literature (1980-2002). Journal of Vocational Behaviour, Vol. 66, 124-197

Edwards, J. R., \& Rothbard, N. P. (2000). Mechanisms linking work and family: Clarifying the relationship between work and family constructs. Academy of Management Review, 25, 178-199

Eikhof R. D., Warhurst C., Haunschild A. (2007). Introduction: What work? What life? What balance? Critical reflections on the work-life balance debate, Employee Relations Vol. 29 No. 4, 325-333

Frone, M.R. (2003). Work-family balance, in Quick, J.C. and Tetrick, L.E. (Eds). Handbook of Occupational Health Psychology, American Psychological Association, Washington, DC.

Gallie D., Russell H. (2009). Work-Family Conflict and Working Conditions in Western Europe, Social Indicator Research 93, 445-467

Greenhaus, J. H., \& Powell, G. N. (2006). When work and family are allies: A theory of 
work-family enrichment. Academy of Management Review, 31, 72-92

Greenhaus, J.H. and Beutell, N.J. (1985). Sources of conflict between work and family roles. Academy of Management Review, Vol. 10, 76-88

Grzywacz, J. G. (2002). Toward a theory of work-family facilitation. Paper presented at the 34th Annual Theory Construction and Research Methodology Workshop, Houston, TX.

Hackman, J.R. and Oldham, G.R. (1976). Motivation through the design of work: test of a theory, Organizational Behaviour and Human Performance, Vol. 16, 250-279

Hanson G.C., Hammer L.B., Colton C.L. (2006). Development and Validation of a Multidimensional Scale of Perceived Work-Family Positive Spillover. Journal of Occupational Health Psychology, Vol. 11, No. 3, 249-265

Heraty N. Morley M. J., Cleveland J.N. (2008). The work-family dyad: multi-level perspectives. Journal of Managerial Psychology, Vol. 23 No. 5, 477-483

Higgins, C., Duxbury, L. and Johnson, K.L. (2000). Part-time work for women: does it really help balance work and family? Human Resource Management, Vol. 39 No. 1, 17-32

Hsu Y.R.( 2011 ). Work-family conflict and job satisfaction in stressful working environments. The moderating roles of perceived supervisor support and internal locus of control, International Journal of Manpower Vol. 32 No. 2, 233-248

Huang Y-H., Hammer, L.B; Neal, M.B.; Perrin, N. A (2004). The Relationship Between Work-to-Family Conflict and Family-to-Work Conflict: A Longitudinal Study. Journal of Family and Economic Issues; Spring; 25, 1, 79-100

Hughes J., Bozionelos N. (2007). Work-life balance as source of job dissatisfaction and withdrawal Attitudes An exploratory study on the views of male Workers. Personnel Review Vol. 36 No. 1, 145-154

Hyman J., Summers J., (2007). Work and life: can employee representation influence balance? Employee Relations, Vol. 29 No. 4, 367-384

Kasper H., Meyer M., Schmidt A. (2005). Managers dealing with work-family-conflict: an explorative analysis. Journal of Managerial Psychology; 20, 5/6; 440- 461

Kossek, E.E. and Ozeki, C. (1998). Work-family conflict policies and the job-life satisfaction relationship: a review and directions for organizational behaviour-human resources research. Journal of Applied Psychology, Vol. 83, 139-149.

Kowalewski J. Ed. (2007). Telepraca w sektorze małych i średnich przedsiębiorstw, Leszno: Wyższa Szkoła Marketingu i Zarządzania w Lesznie

Lambert, S.J. (2000). Added benefits: the link between work-life benefits and organizational citizenship behaviour. Academy of Management Journal, Vol. 43, 801-815

Locke E. A. (1976). The nature and causes of job satisfaction. Handbook of industrial and organizational psychology, Chicago, IL: Rand McNally College Publishing Company. 
Lourel M., Ford M.T., Gamassou C.E., GueguenN., Hartmann A. (2009). Negative and positive spillover between work and home Relationship to perceived stress and job satisfaction. Journal of Managerial Psychology, Vol. 24 No. 5, 438-449

Malik M. I., Saleem F.,Ahmad M. (Apr-Jun 2010). Work-Life Balance and Job Satisfaction Among Doctors in Pakistan. South Asian Journal of Management; 17, 2, 112 - 123

Marcinkus C.W., Whelan-Berry K.S., Gordon J.R. (2007), The relationship of social support to the work-family balance and work outcomes of midlife women. Women in Management Review Vol. 22 No. 2, 86-111

Md-Sidin S., Sambasivan M., Ismail I. (2010). Relationship between work-family conflict and quality of life. An investigation into the role of social support. Journal of Managerial Psychology, Vol. 25 No. 1, 58-81

Melrona K.; Finian B. (2004). The Influence of Support Relationships on Work-Family Conflict: Differentiating Emotional from instrumental support. Equality, Diversity and Inclusion: An International Journal; 23, 1/2, 78 -95

Moore F. (2007). Work-life balance: contrasting managers and workers in an MNC, Employee Relations Vol. 29 No. 4, 385-399

Morganson V.J., Major D.A., Oborn K.L., Verive J.M., Heelan M.P. (2010). Comparing telework locations and traditional work Arrangements. Differences in work-life balance support, job satisfaction, and inclusion. Journal of Managerial Psychology Vol. 25 No. 6, $578-595$

Nair P. K. (2007). A Path analysis of relationship among job stress, fob satisfaction, motivation to transfer, and transfer of learning: perceptions of occupational safety and health administration outreach trainers, Dissertation, Submitted to the Graduate Studies of Texas A\&M University.

O'Driscoll, M. P, Brough, P., Kalliath T., (2004) .Work/Family Conflict, Psychological Well-Being, Satisfaction and Social Support: A Longitudinal Study in New Zeland. Equality, Diversity and Inclusion: An International Journal,23, 1/2; 36- 56

Peeters M., Wattez C., Demerouti E., de Regt W. (2009). Work-family culture, work-family interference and well-being at work Is it possible to distinguish between a positive and a negative process? Career Development International Vol. 14 No. 7, 700-713

Peetz D., Muurlink O., Townsend K., Allan C., Fox A. (2011). Quality and Quantity in Work-Home Conflict: The Nature and Direction of Effects of Work on Employees' Personal Relationships and Partners. Australian Bulletin of Labour, Vol 37 No 2,138-162

Pichler F. (2009). Determinants of Work-life Balance: Shortcomings in the Contemporary Measurement of WLB in Large-scale Surveys. Social Indicators Research, 92,449-469

Powell G. N, Greenhaus J. H.( 2006). Managing incidents of work-family conflict: A decision-making perspective. Human Relations; Sep; 59, 9, 1179- 1212 
Saif M. I., Malik M.I., Awan M.Z. (2011). Employee Work Satisfaction and Work - Life Balance: A Pakistani Perspective. Interdisciplinary Journal of contemporary research in Business, Vol. 3 No 5, $606-617$

Saltzstein, A.L, Ting Y., Hall Saltzstein G. (2001). Work-family balance and job satisfaction: The impact of family-friendly policies on attitudes of federal government employees. Public Administration Review; Jul/Aug 2001; 61, 4, 452-466

Schieman S., Young M.(2011). Economic Hardship and Family-to-Work Conflict: The Importance of Gender and Work Conditions. Journal of Family and Economic Issues, 32, $46-61$

Seery B.L., Corrigall E.A., Harpel T. (2008). Job-Related Emotional Labor and Its Relationship to Work-Family Conflict and Facilitation. Journal of Family and Economic Issues 29,461-477

Spector P. E. (1997). Job satisfaction: Application, assessment, cause, and consequences, Thousand Oaks, CA: Sage Publications.

Springer A. (2011). Postrzeganie pracy, zachowanie kierownika oraz wsparcie społeczne jako wyznaczniki kształtowania postaw pracowniczych, Zeszyty Naukowe Wyższej Szkoły Bankowej we Wrocławiu, 24/2011, 191-204

Staines, L. G. (1980). Spillover versus compensation: A review of the literature on the relationship between work and nonwork. Human Relations, 33, 111-129.

Straub C. (2007). A comparative analysis of the use of work-life balance practices in Europe. Do practices enhance females' career advancement? Women in Management Review, Vol. 22 No. 4, 289-304

Tausig, M., Fenwick, R. (2001). Unbinding Time: Alternate Work Schedules and Work-Life Balance. Journal of Family and Economic Issues; Summer; 22, 2, 101- 119

Thompson, C. and Prottas, D. (2005). Relationships among organizational family support, job autonomy, perceived control, and employee well-being. Journal of Occupational Health Psychology, Vol. 10 No. 4, 100-118.

Tremblay, D. G., Paquet R., Najem, E. (2006). Telework: A Way to Balance Work and Family or an Increase in Work-Family Conflict? Canadian Journal of Communication;31, 3, 715-731

Vroom V. H.(1964). Work and motivation, New York: Wiley.

Wadsworth, L.L; Owens, B.P. (2007). The Effects of Social Support on Work-Family Enhancement and Work-Family Conflict in the Public Sector, Public Administration Review;67, 1; 75- 86

Walker E., Wang C., Redmond J.(2008) .Women and work-life balance: is home-based business ownership the solution? Equal Opportunities International Vol. 27 No. 3, 258-275

Warner M.A., Hausdorf P.A.(2009). The positive interaction of work and family roles. Using 


\section{Macrothink}

need theory to further understand the work-family interface, Journal of Managerial Psychology Vol. 24 No. 4, 372-385

Wayne, J.H., Musica, N. and Fleeson, W.(2004). Considering the role of personality in the work-family experience: relationships of the big five to work-family conflict and positive spillover. Journal of Vocational Behaviour, Vol. 64 No. 1, 108-130

Wayne, J.H., Randel, A.E. and Stevens, J. (2006). The role of identity and work-family support in work-family enrichment and its work-related consequences, Journal of Vocational Behaviour, Vol. 69 No. 3, 445-461

\section{Glossary}

WFC - work - family conflict

JS - job satisfaction

PWtoH - problems work to home

\section{Copyright Disclaimer}

Copyright for this article is retained by the author(s), with first publication rights granted to the journal.

This is an open-access article distributed under the terms and conditions of the Creative Commons Attribution license (http://creativecommons.org/licenses/by/3.0/). 